\title{
Le Style n'existe pas:
}

\section{How migration shaped the "graphic design nation"}

\author{
Panel Chair
}

Davide Fornari / SUPSI University of Applied Sciences and Arts of Southern Switzerland / Lugano / Switzerland

Robert Lzicar / Bern University of the Arts / Bern / Switzerland

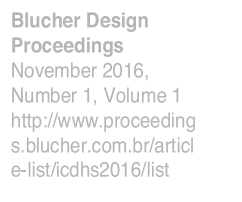

\section{Panel abstract}

Theories developed in Switzerland throughout the 20th century have shaped international practice in graphic design and visual communication down to the present today. At the same time, the development and dissemination of these theories can be traced back to the migration of objects, people and ideas, as well as to corresponding economic and political decisions. This topic most recently gained prominence with the acceptance of the Swiss immigration referendum in February 2014.

This panel discusses different forms, meanings and consequences of both internal and external migration in the context of Swiss graphic design by focussing on the following case studies:

1. Exporting Swissness: Swiss Traditions and Visual Stereotypes in Contemporary Graphic Design

2. The Weiterbildungsklasse für Grafik, Basel School of Design 1968-1988: Dispersing "Swiss Style" through Education

3. Walter Ballmer: Designing Networks Between Switzerland and Italy

4. The Diffusion of the Swiss Style in America: Jacqueline Casey and the MIT Based on these case studies, this panel argues that migration contributed to the development of "Swiss graphic design" from a style into an asset that is part of national heritage - a fact that was confirmed in 2014 when it was one of eight Swiss candidates proposed to UNESCO as Intangible Cultural Heritage. This makes mandatory a critical discussion of the branding of Switzerland as a "graphic design nation".

\section{Keywords}

Graphic design history, national identity, migration, Swiss Style, geographic dispersion

PAPER \#1

\section{Exporting Swissness:}

\section{Swiss traditions and visual stereotypes in contemporary graphic design}

Sara Zeller / University of Bern / Bern / Switzerland

Robert Lzicar / Bern University of the Arts / Bern / Switzerland

\begin{abstract}
"Swissness" is a label established in the 1990s to brand products and services made in Switzerland. Until today it is associated with values such as quality, accuracy, reliability and heritage. It has since expanded to encompass political and cultural issues. According to that development, visual references to "Swissness" can not only be found in product or tourist advertisements, but also in recently designed posters in the field of culture. In contrast to the market-oriented patriotism promoted by traditional definitions of Swissness, these artefacts contribute to alternative
\end{abstract}


images of Swiss national identity and disseminate them through graphic design exhibitions all over the world. This becomes particularly relevant as Swiss graphic design and typography has recently been announced as candidate for the UNESCO list of Intangible Cultural Heritage, suggesting graphic design culture in Switzerland itself is associated with Swissness. This paper analyses three posters from the exhibition Stealing Swiss (Samwon Paper Gallery, Seoul, 10.20.-12.6.2014) and discusses how they question national stereotypes promoted by Swissness and support alternative approaches to it.

\section{Keywords}

Graphic design, visual culture, visual stereotypes, national identity, Swissness

\section{Introduction}

The exhibition Stealing Swiss took place at the Samwon Paper Gallery, Seoul, from October 10, to December 6 , 2014. It presented an overview of contemporary graphic design from Switzerland including different media such as posters, books, brochures, leporellos and flyers, and offered a wide range of design approaches (Lzicar \& Zeller 2015) (see Figure 1). A significant number of posters in the exhibition visually referred to Swiss customs. The present paper examines these posters as representatives of Swissness, considering the traditions and stereotypes on which the design of these posters focuses, and how these are interpreted in a "designerly" way. Besides these aspects, the exhibition itself could be said to have been representative of Swissness by using the nationality as a quality label, as its title suggests. It thereby contributed to the construction of alternative images of Swiss national identity. But what are these images, and how do they change their meaning when they are presented in a different cultural context such as in Korea?

The branding of products as "made in Switzerland" became popular during the interwar period. But already as early as the late 1910s the Swiss flag was used to label goods from Switzerland, and this was later followed by a stylized crossbow (Horber, 2008, p. 34). One possible reason for the introduction of this label is that Switzerland is a small country without many natural resources. To be competitive in a growing international marketplace, Swiss companies and authorities created campaigns and marketing strategies to construct and promote the reputation of Swiss-made goods. That Switzerland was able to establish itself as a "chocolate nation," even though chocolate mainly consists of resources imported from abroad, can serve as proof of the success of those efforts (Huguenin, 2013, p. 150). "Präsenz Schweiz" ("Presence Switzerland"), an organizational unit of the Swiss Federal Department of Foreign Affairs that deals with questions of public diplomacy and nation branding, conducted a study in 2006 that showed how Switzerland's image abroad is strongly influenced by stereotypes: So Switzerland is still associated mainly with watches, chocolate and cheese (Buchser, 2009), while stereotypes in tourism advertisements might also support this perception (Tissot, 2012). The Swiss usually claiming not to be especially patriotic can even be considered as "fundamentally hypernationalistic" when it comes to tourism posters. The repeated use of symbols is regularly explained by strengthening the unity of Switzerland as a nation lacking a shared language as unquestioned smallest denominator (Signer, 2010, p. 29).

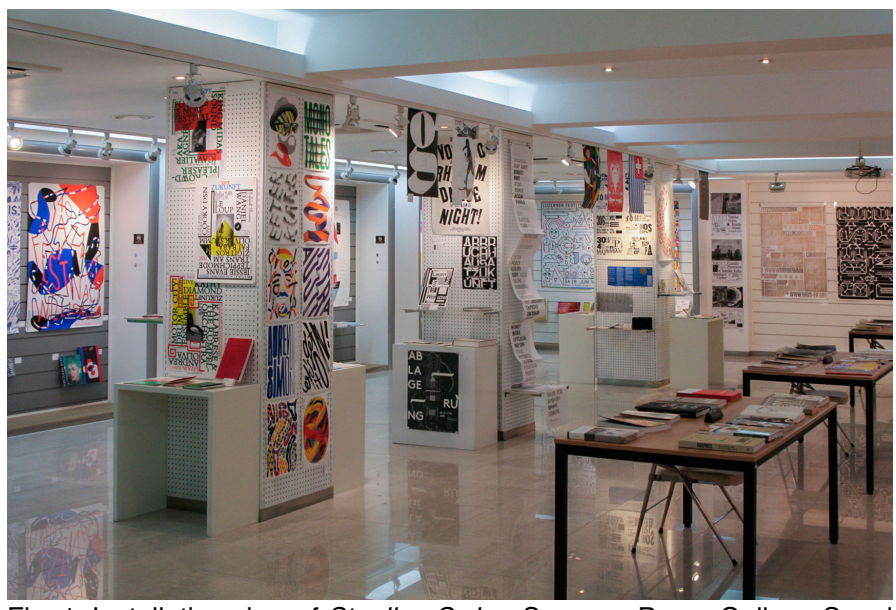

Fig. 1: Installation view of Stealing Swiss, Samwon Paper Gallery, Seoul 20.10.-6.12.2014. (C) Samwon Paper Gallery

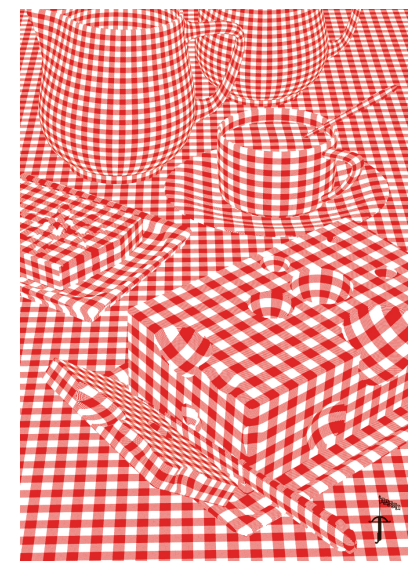

Fig. 2: Poster "Käseunion Neue" (Poster for the exhibition "Switzerland: Design for Life" at A Foundation, London) by Reto Moser, Tobias Rechsteiner, and Simon Renfer, 20102 
Driven by the success of national branding in the tourist industry, symbols like the national flag expanded their use to labeling products from Switzerland on the global market. As a result, Switzerland has been associated with a high standard of quality for a long period, but today the established image leaves an impression of being somewhat dreary and out of date. The term Swissness emerged in the late 1990s to position Switzerland as a trendy lifestyle brand at home and abroad (Tanner, 2007). Most recently, the Swissness legislation to protect and promote high-quality "Swiss products and services" was passed by the government and will come into force in January 2017 ("The new 'Swissness' legislation," 2015).

In summary, Swissness has been created as a marketing term to add Swiss made products and services a symbolic value and developed to brand Switzerland as a nation with distinctive characteristics, but also has supported nationalism. It can be reasonably assumed that visual culture has played a significant role in these processes until today. However, a significant number of contemporary Swiss graphic designers take a critical view of Swiss national identity. By appropriating graphic products, symbols and cultural traditions, their posters reveal stereotypes and create individual images of Switzerland.

This paper examines three posters from the exhibition Stealing Swiss with regard to their interpretation of Swissness. We selected the posters, because some elements obviously refer to Swiss visual culture. First, we will describe the design of the poster, focusing on those elements. Secondly, we will analyze the posters within their historical context by comparing them to other visual products or with reference to why they where originally designed. To gather more information on the design processes, we consulted the designers via email. Thirdly, we will interpret the poster from a perspective of the construction of national identity. The paper will conclude with a discussion of how the exhibition in Seoul disseminated alternative images of Swissness beyond common national stereotypes.

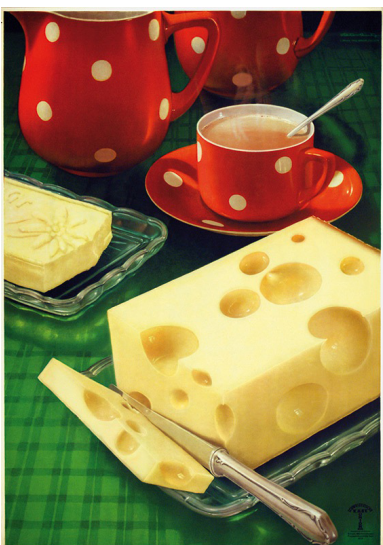

Fig. 3: Poster without text by Viktor Rutz (client: Schweizerische Käseunion AG), 1938

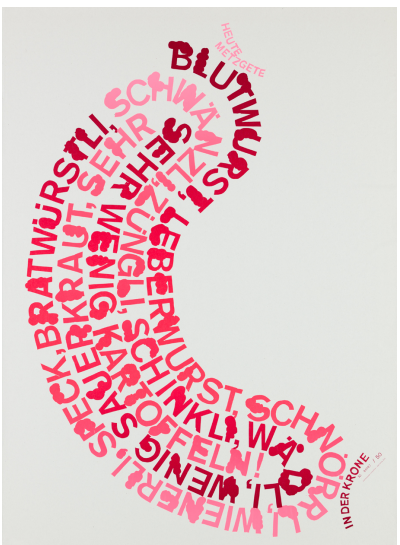

Fig. 4: Poster "Heute Metzgete" by Dafi Kühne, 2011. Reproduction by Museum für Gestaltung, Plakatsammlung, Franz Xaver Jaggi, 2015

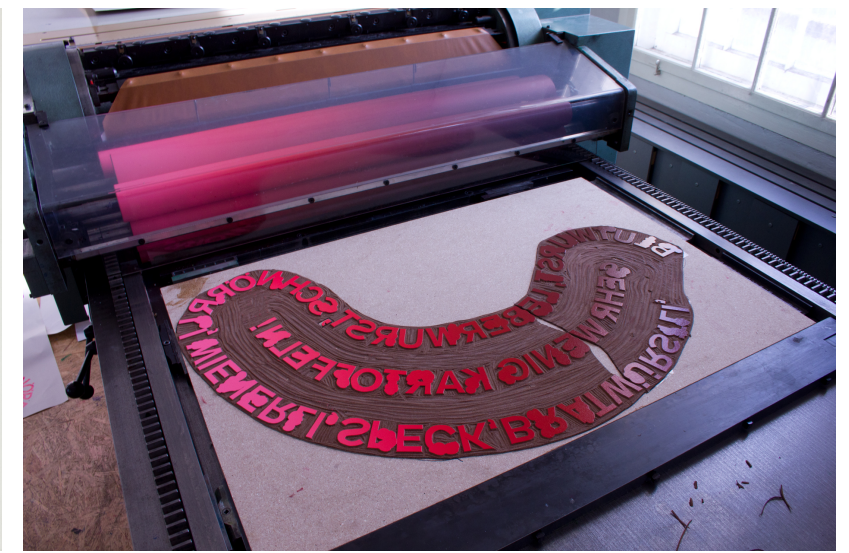

Fig. 5: Linocut printing of the poster "Heute Metzgete." Photograph by Dafi Kühne, 2015

\section{From dairy to design}

The poster Käseunion Neue, designed by Reto Moser, Tobias Rechsteiner, and Simon Renfer, presents an "undercover-still-life scenery" including two jugs, a coffee mug with a spoon, butter on its butter dish and a large cheese. The table has been set, and is completely covered by a red-and-white, checkered tablecloth. In the lower right corner, the attentive viewer finds a stylized crossbow with a waving flag on top, spelling "BANG!" (see Figure 2).

Only a few experts would recognize the design as a reinterpretation of a poster by Victor Rutz from 1938, commissioned by the Schweizerische Käseunion (Swiss Cheese Union), a cartel regulating the price and distribution of cheese in Switzerland (Ryser, 2015). The original poster shows the same scene, but uncovered: a checkered green table cloth in front of two cropped characteristic polka-dotted jugs and a similar coffee mug containing coffee with a large dash of milk. Two other typical Swiss food products play a major role in the design: a slab of butter and an Emmental cheese (see Figure 3). The focus on Swiss dairy products is not coincidental. The poster aims to promote these as staple foodstuffs for the home market during a period of economic uncertainty, just before World War 2. Rutz created an iconic still-life illustration of the Swiss custom called Café complet - a cold meal including coffee, milk, butter, bread, jam, cheese and sausage that was typically served for dinner on workdays in the 
French and German-speaking parts of Switzerland. The original version of the poster also has a crossbow in the lower right corner, a typographical logo using the words "Schweizerische Käseunion", thereby indicating the country of origin of the products displayed.

The three designers were commissioned to promote an exhibition of reinterpretations of historical Swiss posters organized by the Swiss Cultural Fund in Britain entitled Switzerland: Design for Life (A Foundation, London, 2011). Käseunion Neue refers to different Swiss products and customs in various ways. By choosing the historical poster of Victor Rutz as their basis, the designers are not only referring to a historical Swiss graphic product, but also to a time when dairy production was an important industry in Switzerland - though in this context, it is substituted by design culture. The iconic red-and-white, checkered tablecloth is still used on the tables of restaurants and in tourism advertisements down to the present day, and can thus be considered a successful Swiss design product. The stylized crossbow refers to the Swiss national hero Wilhelm Tell, who only became widely known in the $19^{\text {th }}$ century, thanks to the play of that name by Friedrich Schiller. But the designers have changed its meaning: The crossbow still labels the poster as "Swiss made," but the "BANG!" at the same time offers a comic-style contrast to this, referring to the crossbow's original function as a weapon. As the exhibition in question showcased young designers and design studios from Switzerland, the poster contrasted typical visual elements of Swissness with elements of a global pop culture to create a cosmopolitan image of a contemporary Swiss design culture.

\section{Anachronistic sausages}

Dafi Kühne's poster Heute Metzgete arranges blotchy red words in the shape of a large sausage. The words "Heute Metzgete" stand at the upper end of sausage, and "in der Krone" at the lower end. This, along with the fact that the poster is printed in meat-like shades of red (see Figure 4), reveals that the poster is advertising a Metzgete in a local restaurant - a Swiss culinary tradition in which one eats freshly slaughtered pork in various forms ranging from blood sausage to liver sausage and bacon, accompanied by sauerkraut and potatoes. This becomes even clearer, as the type-sausage is set from the key components of a traditional Metzgete-plate.

Switzerland has a rich tradition of sausage-making (Heller, 2007). The tradition of the Metzgete goes back to a time when pigs were kept at home and only slaughtered in late autumn so as to conserve their meat during the winter. Even today, a Metzgete makes use of almost every part of the pig and is still served from late September until January in both rural and urban areas of Switzerland (Imhof, 2012, pp. 22-23).

Besides its subject, the poster also refers to this Swiss custom on the level of its production: Being printed as a linocut using the designer's own letterpress (see Figure 5), the production of the poster appears as anachronistic as the event being advertised. Strikingly, the poster was not designed to announce a real Metzgete, but was commissioned to be sold as an art print in a limited edition in an online design shop (Kühne, 2011). The meaning of the poster thus shifts to conveying a notion of Swissness in the kitchens of a design-savvy audience, or to exporting it internationally as part of this exhibition.

\section{Local, not national}

Erich Brechbühl's poster Anne Bäbi im Säli appropriates the form of a chalkboard which can typically be found in front of a Beiz to advertise its daily specials - Beiz being the Swiss-German name for a semi-public premises that is something between a pub and a restaurant. In the present instance, the poster announces a play by the Theatergesellschaft Sempach, the local theater company in a small Swiss village. As the upper part of the poster suggests, it is common for these boards to be sponsored by brands from Switzerland and abroad served in the Beiz. In this case, the logotype of the popular Swiss soft drink Rivella is substituted by the name of the theater group. The name of the play in sans-serif letters, Anne Bäbi im Säli, adopts the irregular spacings of carelessly applied letraset type. All other information is handwritten in sloppy letters, as if the writer had been in a rush to write a menu just before lunch was due to be served (see Figure 6).

Rivella, a soft drink based on milk serum, was developed in the 1950s in a small village near Zurich. The product became very popular, began to be sold in other European countries, and found itself promoted to the status of a national beverage in Switzerland. As a Swiss alternative to other, mostly international, soft drink brands, Rivella represents Swissness as a lifestyle (Imhof 2012, p. 45), for instance by using Swiss-German dialect for its advertising campaigns (see Figure 7).

Brechbühl developed a playful concept to promote the theatrical performances by linking the rural aesthetic of the chalkboard with the local focus of the event and the venue ("Buureschopf Wirtschaft Zur 
Schlacht"), a side room of a tavern in the village of Sempach near Lucerne. The poster transfers the perceived qualities of Rivella to the play being performed. The event itself thereby expands its meaning into a representation of Swissness. The poster critically assesses this dying part of Swiss everyday visual culture by drawing attention to how international companies have influenced Swiss visual culture by spreading their brands in local communities all over the country.

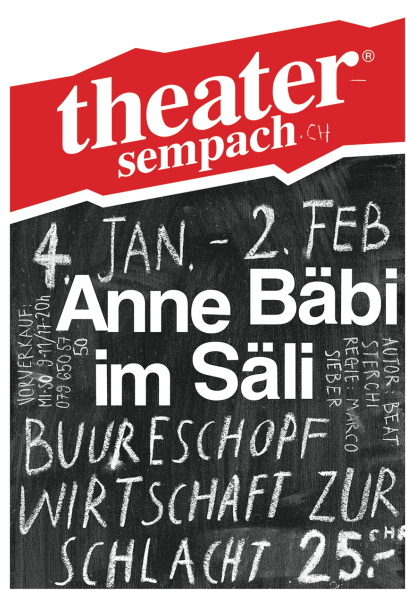

Fig. 6: Poster "Anne Bäbi im Säli” by Erich Brechbühl, 2012.

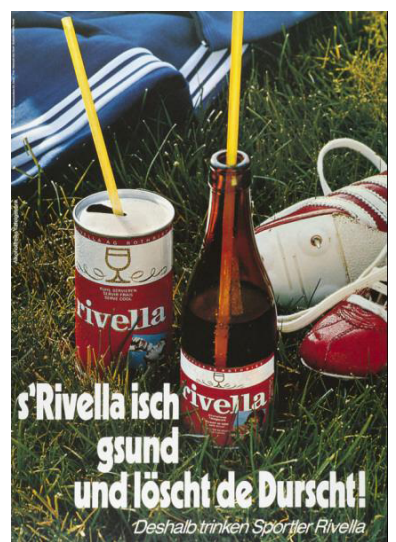

Fig. 7: Poster "S'Rivella isch gsund und löscht de Durscht!" by Pool Advertising + Communications AG Zürich, 1960

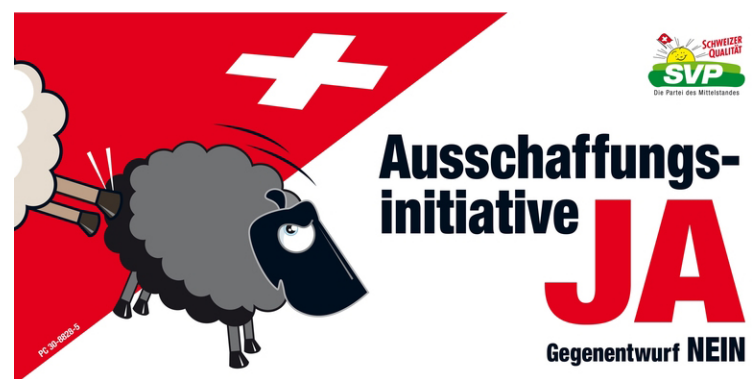

Fig. 8: Poster of the "Schweizerische Volkspartei" (Swiss People's Party) for the deportation of criminal foreigners, 2010. Retrieved April 22, 2016, from https://www.svp.ch/aktuell/medienmitteilungen/staenderatverschleppt-umsetzung-der-ausschaffungsinitiative-weiter/.

\section{Towards a Glocal exchange}

The analysis of these three posters reveals how conscious contemporary Swiss graphic designers engage with the country's visual culture. The images used for their posters - a dining table, a sausage and a chalkboard - evoke collective memories and create identity. On closer inspection, the posters question this identity by overlaying traditions with egalitarianism, by highlighting their archaic dimension, or by pointing out the impact of national economies. The posters thus preserve the heritage of visual culture from Switzerland, but at the same time critically assess Swiss traditions and create new images of Switzerland in a "designerly" way.

Concerning its content and intention, the posters don't advertise for Swiss goods or services, but utilize Swiss cultural characteristics to promote Swiss design abroad, an online design shop or a play by a local theater company. This exemplifies, on the one hand, how Swissness expands its meaning beyond common national stereotypes and market-oriented patriotism. On the other hand, the study indicates a trend towards glocalization meaning the blurring boundaries between the local and the global - in contemporary Swiss graphic design. As argued by Fallan and Lees-Maffei (2016), design has for centuries been simultaneously local, regional, global and national. Globalization and national identity should therefore not be perceived as binary terms, but rather as inseparably intertwined processes. Coming back to the exhibition Stealing Swiss at which the three selected posters were presented, the combination of a national scope and global exchange is central to the concept developed by the curators and graphic designers Erich Brechbühl and Noel Leu. Located in Seoul and designed as a traveling exhibition, Stealing Swiss supports the dissemination of alternative images of Swiss national identity abroad.

Bearing in mind that national stereotypes are a well-known phenomenon in Swiss politics - particularly on posters and flyers of the right-wing populist political party "Schweizerische Volkspartei" (Swiss People's Party), where myths are strategically turned into stereotypes for use in both foreign and internal affairs (Tanner 1998, p. 27) (see Figure 8) - exhibitions like Stealing Swiss indicate a growing relevance for future research in terms of Swiss foreign policy.

\section{References}

Buchser, C. (2009, August 25) 'Verzerrte Wahrnehmung der Schweiz', swissinfo. Retrieved January 24, 2016, from http://www.swissinfo.ch/ger/verzerrte-wahrnehmung -der-schweiz/163102.

Fallan, K. and Lees-Maffei, G. (2016) 'Real Imagined Communities: National Narratives and the Globalization of Design History', in Design Issues, vol. 32, no. 1, Winter, pp. 5-18.

Feige, S. (2012) 'Die Marke Schweiz: Schweizer Stereotypen als Element einer Marketing- und Verkaufsstrategie', in Engler, B. (ed.) Wir und die Anderen: Stereotypen in der Schweiz, Academic Press Fribourg, pp. 245-260. 
Heller, A. (2007) Um die Wurst: Metzgermeister der Schweiz, Basel: Echtzeit Verlag.

Horber, R. (2008) 'Labelpflege - Mit der Armbrust', in Management und Qualität, no. 6, pp. 34-35.

Huguenin, R. (2013) 'The Swiss Milk Chocolate: A Typical Image for an Atypical Product', in Ceccarelli, G., Grandi, A., and Magagnoli, S. (eds.) Typicality in History: Tradition, Innovation, and Terroir, Brussels: Peter Lang, pp. 149-163.

Imhof, P. (2012) Das kulinarische Erbe der Schweiz, Basel: Echtzeit Verlag.

Kühne, D. (2011, November) Küchenplakat / Heute Metzgete. Retrieved January 24, 2016, from http://www.babyinktwice.ch/index48.php\#.

Lzicar, R. and Zeller, S. (2015) 'Arts, Crafts and Wealth. An Overview Of The 'Stealing Swiss' Exhibition', in Oh, Y. and Park, F. K. (eds.) Stealing Swiss, Seoul: CMYK Publications, pp. 38-43.

Ryser, D. (2015) 'Bundesanstalt oder Kartell? Die Aushandlung des Verhältnisses zwischen Staat und Schweizerischer Käseunion, 1933-1939', in David, T., Straumann, T., Täuscher, S. (eds.) Neue Beiträge zur Wirtschaftsgeschichte - Nouvelles contributions à l'histoire économique, Schweizerisches Jahrbuch für Wirtschafts- und Sozialgeschichte / Annuaire Suisse d'histoire économique et sociale, vol. 30, Zurich: Chronos Verlag, pp. 125-141.

Signer, D. (2010) 'Schweizerkreuz, Heidi, Alphorn, Tell: Die Geschichte einer Obsession', in Museum für Gestaltung Zürich (ed.) Poster Collection 21: Paradies Schweiz, Baden: Lars Müller Publishers, pp. 14-19.

Tanner, J. (1998) 'Nationale Identität und kollektives Gedächtnis: Die Schweiz im internationalen Kontext', in Kanyar, H. (ed.) Die Schweiz und die Fremden. 1798 -1848-1998: Begleitheft zur Ausstellung, Öffentliche Universitätsbibliothek Basel, pp. 22-36.

Tanner, J. (2007, November 30) 'Das neue Wohlbehagen im Kleinstaat', Tages-Anzeiger, pp. 53.

The new "Swissness" legislation (2015, December 15), Swiss Federal Institute of Intellectual Property. Retrieved January 24, 2016, from https://www.ige.ch/en/indications-of-source/swissness.html.

Tissot, L. (2012) 'La magie de la montagne ou du bon usage des stéreotypes dans l'imaginaire touristique helvétique $\left(19^{\mathrm{e}}-20^{\mathrm{e}}\right.$ siècles)', in Engler, B. (ed.) Wir und die Anderen. Stereotypen in der Schweiz, Academic Press Fribourg, pp. 231-243.

\title{
Biographical note
}

Sara Zeller (MA) studied Art History in Zurich, Berlin and Bern. Currently she is writing her PhD thesis at the University of Bern in the field of contemporary Swiss graphic design. She works as a freelance curator and author in Switzerland.

Robert Lzicar (MA) is a communication designer, educator and researcher. At the Bern University of the Arts, he directs the MA Communication Design, researches at the Department of R+D Communication Design, and teaches graphic design history. $\mathrm{He}$ is a $\mathrm{PhD}$ candidate at the Graduate School of the Arts, Bern.

\section{The international Weiterbildungsklasse für Grafik, Basel School of Design 1968-1988: Dispersing "Swiss Style" through education}

\author{
Leslie Katherine Kennedy / Academy of Art and Design / Basel / Switzerland
}

\begin{abstract}
Throughout Switzerland, expertly trained typographers, and designers emerged from the postwar European malaise, as a community with shared goals, strategically aimed at enhancing economic development. The international desire to reproduce this intangible Swiss attitude towards aesthetic, and serviceable design, encouraged educators to expand their endeavors to accept students from outside Switzerland.

Thus, the modernist pedagogic syllabi implemented within the Basel School of Design's Graphikfachklasse (vocational graphic design program) was extended to include a postgraduate program; the Weiterbildungsklasse, which was conceived to attract international students.

From its inception, the reputation of the Weiterbildungsklasse spread rapidly, making Basel a mecca for young multinational designers and design educators (from e.g., Asia, North and
\end{abstract}


South America), who would then, geographically disperse Swiss design methodology and tenets - through both practice and teaching - around the world.

Albeit, much of the Weiterbildungsklasse's syllabi leaned heavily on the school's traditional design syllabi, the innovations of Emil Ruder, Armin Hofmann, Wolfgang Weingart, et al, still underpins the school's renown.

While the Basel approach to modern typography has been extensively documented, the flipside of the school's curriculum, those exercises used to create images by training exacting brush and drawing skills, has long deserved the same degree of attention. These acquired techniques would become an embodied resource for form-based outcomes (e.g. symbols, logos, pictograms).

This presentation's perspective will be to contribute findings from recent research - e.g. transcribed interviews, collected syllabi and curriculum - to contemporary discourses considering how the Basel Weiterbildungsklasse would influence the geographic dispersion of the concept "Swiss Style".

\title{
Keywords
}

Basel School of Design, Weiterbildungsklasse für Grafik, Syllabi, Methodology, Geographic dispersion

\section{Biographical note}

Leslie Kennedy, a former student of the Weiterbildungsklasse at Basel School of Design, followed by years as an Art Director, joined the Master's program at the FHNW in Basel, where she was granted a MA for her thesis concerning the didactic and methodological approaches of the Basel School of Design.

PAPER \#3

\section{Walter Ballmer:}

\section{Designing networks between Switzerland and Italy}

Davide Fornari / SUPSI University of Applied Sciences and Arts of Southern Switzerland / Lugano / Switzerland

\begin{abstract}
Walter Ballmer was one of the most prolific Swiss graphic designers active in Milan, where he lived and worked for almost his entire career after being trained in Basle.

Until now Ballmer's work has been neglected although it should be considered as a pivotal connection between Swiss and Italian graphic design for its capacity to build on transnational networks with fellow colleagues and clients at studio Boggeri (where he started his career) and Olivetti, magazines, and professional associations.

Ballmer, an AGI member and recipient of Compasso d'Oro award, was the designer behind many internationally acclaimed brands (e.g. Roche, Valentino, Olivetti), and was able to develop an entrepreneurial 'studio' approach, which was a successful strategy in such a difficult market as post-boom Italy.

Oral interviews and archival research made available unpublished materials that enlighten the role and specificity of Ballmer in the Italian context.
\end{abstract}

\section{Keywords}

Walter Ballmer, Italian design, Graphic design history, Olivetti, AGI

\section{Introduction and methodology}

This paper reports on a case study from a larger research project on the history of Swiss graphic design: "Swiss Graphic Design and Typography Revisited", financed by the Swiss National Science Foundation in the framework of 
their Sinergia program for the years 2016-2019.

The study of Walter Ballmer's career constitutes a case study whose aim is to examine the visual artefacts produced by Ballmer during his stay in Italy as an employee of Studio Boggeri (1947-1955), art director at Olivetti (1956-1970) and principal designer of Unidesign (1971-1990s), using a historical approach mixed with ethnomethodology (deep immersion, informed interviews) as opposed to ethnographic methods (Pollner, Emerson 2001). The research has begun with the collection of archival material in Italy and Switzerland. The following step is to conduct a series of around 15 semi-structured interviews with contemporary witnesses (Ballmer's family and assistants, Giorgio Lucini, Bruno Monguzzi, Felice Nava, Urs Glaser, Anna Monika Jost and Fulvio Ronchi). The resultant data will be brought together and analyzed according to a framework defined in the current literature on the history of graphic design in Italy and Switzerland. Unidesign archives are currently not available to the public. Materials originating from Unidesign can be found with clients' archives such as Archivio Storico Olivetti (Ivrea), Valentino (Rome) and others. The collection and close reading of these materials aims at reconstructing the archive as an atlas where the 'memory of the projects' and their networks are the focal point of research (Gunetti 2009). The focus is not Walter Ballmer or Unidesign per se, but rather the microcosm of a graphic design studio established by a Swiss graphic designer abroad and the networks and relationships that it was able to create.

\section{Historical context}

Walter Ballmer was one of the most prolific Swiss graphic designers working in Italy, where he lived for almost his entire career after being trained in Basle. "The arrival of Swiss designers in Italy, on the Zurich-Milan axis, has often been seen in terms of a successful marriage between a kind of functional and calculated Swiss prose and an Italian impromptu poetic vein" (Vinti 2013, p. 28). Yet, according to Richard Hollis, "in Italy it was difficult to separate what was Italian from what was imported from neighbouring Switzerland" (Hollis 2006, p. 255). The osmosis between Swiss and Italian designers worked so well that "today [...] it would scarcely come into anyone's head to call personalities like Max Huber or Walter Ballmer Swiss designers" (Höger 2007, p. 42). But as Vinti puts it: "the picture becomes far more complex and nuanced" (Vinti 2013, p. 28), while the current opinion seems to be the result of simplifications or prejudices regarding the Swiss and Italian graphic traditions (Fioravanti, Passarelli, Sfligiotti 1997; Baroni, Vitta 2003; Georgi, Minetti 2011; Camuffo, Piazza, Vinti 2012; Lees-Maffei, Fallan 2014).

Walter Ballmer (Liestal 1923 - Milan 2011), after studying in Basle at the Kunstgewerbeschule ("School of arts and crafts") (1940-1944), moved to Milan to work for Studio Boggeri in 1946, where he refined his technical and cultural skills (Monguzzi 1981, pp. 57, 60, 62-67, 70; Waibl 1988, pp. 134-135; Odermatt 1998, p. 14). In 1956 Adriano Olivetti hired him with an exclusive contract for the advertising office. Ballmer redesigned the Olivetti logo (1970), in the framework of a cultural and corporate policy that Vinti called 'industrial style': a corporate identity built within the company instead of being outsourced to other professionals (Vinti 2007). One can perceive the Swiss roots of Ballmer's advertising campaigns for Olivetti, based on the sole use of typography, yet they are just early examples of a 'manner' that was spreading, not necessarily only through Swiss graphic designers in Italy (Piazza 2012, p. 22). In 1971, Ballmer founded his own office in Milan, Unidesign: the clients were some of the most significant Italian brands, such as Nava or Valentino Garavani, whose logos Ballmer designed (Ballmer 2003). In 1971, he became a member of AGI (Bos, Bos 2008), after winning the Compasso d'Oro award in 1954 and best Swiss poster award in 1961.

The work of Walter Ballmer has been mostly neglected thus far, while his work as art director at Olivetti and as a founding member of Unidesign was pivotal in connecting the Swiss and Italian graphic design scenes (Ballmer 1981; Monguzzi 1981, pp. 57, 60, 62-67, 70; Waibl 1988, pp. 134-135; Odermatt 1998, p. 14; Ballmer 2003; Piazza 2012, p. 22; Lzicar, Fornari 2016). Ballmer was the designer behind many internationally acclaimed brands (e.g. Roche, Valentino, Olivetti) and was able to develop an entrepreneurial "studio" approach, that is, being recognized for technical skills or a specific task - in his case, logo design - which was a successful strategy in such a difficult market as post-boom Italy (Vinti 2007). His oeuvre is of particular interest because of his connections to fellow designers (through his participation as a member to AGI and ADI - Associazione per il Disegno Industriale).

\section{Intermediate results}

The research project is in the beginning of its first of three years. While the Ballmer archives are not available due to a family decision, working materials have been found in clients' archives and his assistants' archives. The Studio 
Boggeri archives have not yet been investigated. A number of institutions and people remain to be interviewed, yet an already consistent amount of unpublished material has emerged, shedding light on Ballmer's practice.

The Archivio Storico Olivetti in Ivrea contains most of the material belonging to the Olivetti Company from 1908 to the end of the $20^{\text {th }}$ century. While neatly organized, it is often difficult to track graphic design artifacts as they were seldom credited to the designers due to a company policy which did not allow in-house designers to sign their works. Nevertheless, a large number of works by Ballmer has highlighted his intensive practice as one of the four art directors active at the same time at Olivetti during the years 1956-1970. The analysis of Graphis annuals from that period have confirmed the fact that all printed material from Olivetti was signed and published as 'Olivetti Ufficio Pubblicità' (“Advertising Office”).

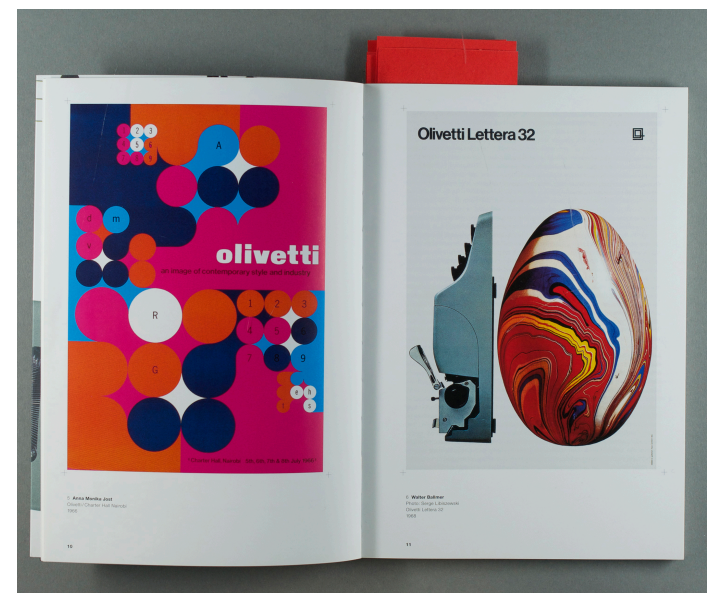

Fig. 1: Walter Ballmer with Anna Monika Jost, Olivetti. An Image of Contemporary Style and Industry, offset printing, Arti grafiche Pizzi, Milano, $84 \times 59.5 \mathrm{~cm}, 1966$ (left); Walter Ballmer (ph. by Sergio Libis), Olivetti Lettera 32, offset printing, Safgra, Milano, $68.5 \times 48.5 \mathrm{~cm}, 1968$ (right); spread from Zürich-Milano, edited by Bettina Richter, Baden: Lars Müller Publishers, 2007, pp. 10-11, ph. by the author.

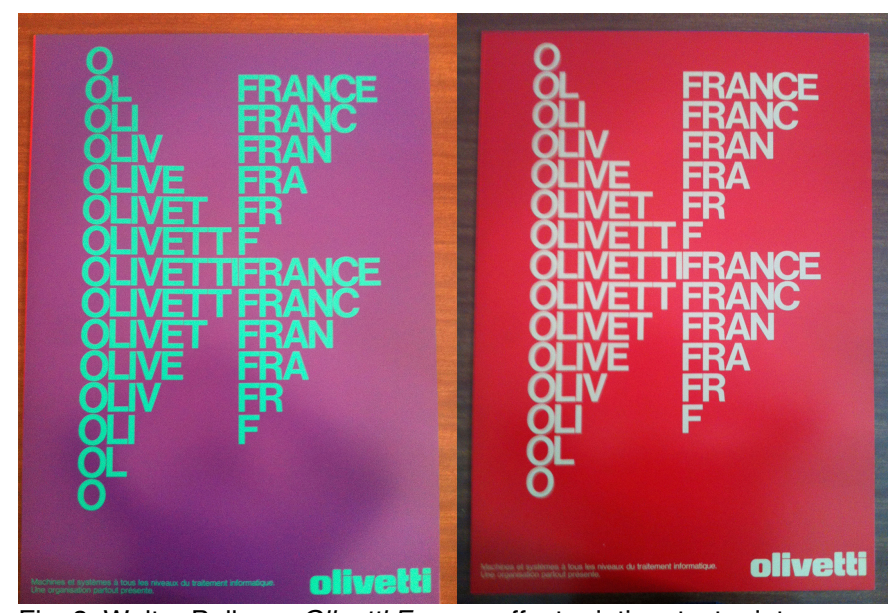

Fig. 2: Walter Ballmer, Olivetti France, offset printing, test prints, Grafiche Nava, Milan, $50 \times 70 \mathrm{~cm}$ ca, 1975, ph. by the author, courtesy of Fulvio Ronchi archives.

In 1970 Ballmer started his own office, and kept working for Olivetti as a consultant, devoting nearly two years to the redesign of the Olivetti logotype. This task was crucial in his career and influenced his future commission-givers. The Olivetti logotype changed many times since 1908, with different version designed by Xanti Schawinsky, Marcello Nizzoli, and Giovanni Pintori. Ballmer's contribution coincided with the peak of the company's global expansion, and the need for a corporate identity for worldwide markets. But prior to this task, Ballmer was responsible for developing commercial campaigns for typing machines, calculators, and especially the line of Olivetti office furniture called Synthesis. The catalogues and leaflets for Synthesis show proof of the self-promotion and networking capacity of Ballmer: in many of the interiors showcasing the furniture he included abstract paintings and silk-screenings from his artistic practice. Like many other Swiss and Italian designers, Ballmer paired his design career with less known research in visual arts, typically in the so called Konkrete Kunst ("Concrete art"), thus connecting with the likes of Franco Grignani, Tomás Maldonado, Bruno Munari, and especially Max Huber, Richard Paul Lohse, and Carlo Vivarelli.

Investigation at the Olivetti archives also proved the strong connections between Olivetti and Wertheim, a department store in Spain which had a close relationship with the Italian company through members of the board of advisors and joint marketing activities since the 1930s. Ballmer designed an entire corporate identity system for them.

Archival research at maison Valentino in Rome was only partially successful: the company has been sold four times since its establishment, and while the archives are perfectly organized and digitized, it was only possible to highlight the precise year of the activity of Ballmer and infer its reasons. According to the public relations manager at Valentino, until the 1970s maison Valentino changed logotype and brand every other season. The name was more recognizable than the brand itself. The market had been thus far limited to Italy, while from the beginning of the 1970s onwards Valentino's international fame boomed. Thus, Giancarlo Giammetti, manager of maison Valentino, found in Ballmer a 'technician' able to build a brand: a capital 'v' set in Bodoni encapsulated in an elliptical shape, which was registered as a trademark and still used nowadays with few corrections. Even though the logotype 
has changed over the years, Ballmer's brand for Valentino has been kept and used on labels, advertising campaigns, and branded fabrics.

The interviews with former assistants of Ballmer have been extremely interesting, as they have conveyed a fresher insight into the life and practice of a graphic designer mostly unknown beyond the usual biographic profiles compiled for catalogues and annuals. Anna Monika Jost (Klosters-Serneus 1944) and Fulvio Ronchi (Milan 1950) were two of Ballmer's assistants at Olivetti in different periods. They never met or knew of each other, yet they reported very similar experiences while working at Olivetti under Ballmer as art director.

Anna Monika Jost arrived fresh from the foundation course at Zurich School of Arts and Crafts to Milan and started working as a freelance for Ballmer at the Olivetti offices. Her job position was never official, and for this reason oral history is a key in this case study: the Olivetti archives do not show proof of her work for the company as she was paid by the hour as a consultant in the years 1966-1967. Fulvio Ronchi was employed to help Ballmer in the redesign of the Olivetti logotype in 1969-1970. He defined the practice of Ballmer as extremely calculated, based on geometrical and mathematical rules, and as a whole very slow: Ballmer needed to motivate every single choice taken in the design of a poster or a page structure. The design of a poster could take up to two years. Ronchi also reported on the wide use of photographers, model makers, printers, and fine printers in Northern Italy, which points to the considerable financial means available at the time for Olivetti art directors.

Magazines were crucial in the spreading of visual works by Ballmer and Unidesign: Rassegna, Neue Grafik and Pagina hosted projects by Ballmer (Anceschi 1981; Müller 2014). While the reasons and impact for these publications are to be clarified, the connections between Ballmer, Vivarelli and Huber date back to their work at Studio Boggeri in the 1940s, which forged an alliance that remains to be investigated, together with Ballmer's admission to the Alliance Graphique Internationale in 1971.

The draft of a book also emerged from archives: the dummy of a catalogue of Ballmer's work, designed by himself in the manner of many other monographic catalogues devoted to Swiss graphic designers and concrete artists, typically published by $A B C$ Verlag in Zurich or similar publishers in multilingual editions. The book collects images from the works Ballmer considered most representative of his œuvre. It has a double cover and layout: graphic design on one side, visual arts on the other. In the colophon, next to placeholder texts are the coats of arms of the two cantons of Basle (Basel-Stadt and Basel-Land), which testify to Ballmer's wish for public acclaim, as the use of coats of arms would suggest financial backing or at least an endorsement from cantonal authorities. Such a book was never published, yet it witnesses his constant desire to connect two different worlds: Switzerland, where he was born and educated according to the principles of what was later known as Basel School of Design, and Italy, where his career prospered and he spent all his life.

\section{Conclusions}

A pattern emerges from the analysis of material belonging to several Ballmer's clients: from the initial work on advertising campaigns, Ballmer and Unidesign slowly switched across the years to a focus on corporate identities for thenemerging global markets. Olivetti, Wertheim, Valentino, and many more were at the time expanding their operations and needed highly visible and recognizable brands and corporate visual strategies.

Thus, Walter Ballmer was able to become a sort of technician of graphic design, focusing his expertise on logo design and acquiring clients by word of mouth: he was hired from Studio Boggeri to Olivetti; the work at Olivetti helped him connect with Wertheim and Valentino; a similar brief was the base for his work for Colmar.

His double practice as graphic designer and visual artist was also a way to remain connected to his Swiss roots: concrete art was a common practice for both Swiss and Italian artist (Munari 1974), and Ballmer was constantly aiming at this double exposure, be it through visual arts or through his affiliation to professional associations, such as ADI and AGI.

\section{References}

Anceschi, G. (1981) 'll campo della grafica italiana: storia e problemi', Rassegna, vol. 3, no. 6, pp. 5-19. Ballmer, W. (2003) 80, Milan: Lucini.

Baroni, D. and Vitta, M. (2003) Storia del design grafico, Milan: Longanesi.

Bos, B. and Bos. E. (eds.) (2008) AGI. Graphic Design Since 1950, London-New York: Thames and Hudson. 
Brändle, C., Gimmi, K., Junod, B., Reble, C. and Richter B. (eds.) (2014) 100 Years of Swiss Graphic Design, Zurich: Lars Müller Publishers.

Camuffo, G., Piazza, M. and Vinti C. (eds.) (2012) TDM5: grafica italiana, Mantua: Corraini.

Fioravanti, G., Passarelli, L. and Sfligiotti S. (eds.) (1997) La grafica in Italia, Milan: Leonardo Arte.

Georgi, W. and Minetti T. (eds.) (2011) Italian Design is Coming Home. To Switzerland, Otfringen/Barcelona: Polyedra-Actar.

Gunetti, L. (2009) 'An Atlas for a History, a Theory, and a Criticism of Italian Graphic Design: the Case of Albe and Lica Steiner Archive', in Hackney, F. (ed.) Networks of Design. Proceedings of the 2008 Annual International Conference of the Design History Society, Boca Raton (FL): Universal Publishers, pp. 320327.

Hollis, R. (2001) Graphic Design. A Concise History, 2nd edition, London-New York: Thames and Hudson. Hollis, R. (2006) Swiss Graphic Design: the Origins and Growth of an International Style 1920-1965, London: Laurence King.

Hollis, R. (2012) 'The International Style and Italian Graphic Design', in Camuffo, G., Piazza, M. and Vinti C. (eds.) TDM5: grafica italiana, Mantua: Corraini, pp. 34-41.

Lees-Maffei, G. and Fallan, K. (eds.) (2014) Made in Italy. Rethinking a Century of Italian Design, London: Bloomsbury.

Lzicar, R. and Fornari, D. (eds.) (2016) Mapping Graphic Design History in Switzerland, Zurich: Triest Verlag.

Monguzzi, B. (ed.) (1981) Lo studio Boggeri. 1933-1981, Milan: Electa.

Monguzzi, B. (2007) 'Visual Communication as a Question of Translation', in Lichtenstein, C. (ed.) Playfully Rigid. Swiss Architecture, Graphic Design, Product Design 1950-2006, Baden: Lars Müller Publishers, pp. 140-141.

Monguzzi, B. and Ossanna Cavadini, N. (eds.), Bruno Monguzzi. Fifty years of paper 1961-2011, Milan: Skira.

Müller, L. (ed.) (2014) Neue Grafik. New Graphic Design. Graphisme Actuel (1958-1965), reprint of issues no. 1-18, Zurich: Lars Müller Publishers.

Munari, B. (1974) Walter Ballmer, Milan: Sincron

Odermatt, Siegfried (ed.) (1998) 100+3 Swiss Posters, Zurich: Waser Verlag

Piazza, M. (ed.) (2012) Made in Italy Graphic Design. Communication and Companies design oriented 1950-1980, 2nd edition, Milan: aiap edizioni.

Pollner, M. and Emerson, R. (2001) 'Ethnomethodology and Ethnography', in Atkinson, P. et Al. (eds.) Handbook of Ethnography, London: Sage, pp. 118-135.

Vinti, C. (2007) Gli anni dello stile industriale 1948-1965. Immagine e politica culturale nella grande impresa italiana, Venice: Marsilio.

Vinti, C. (2016) Grafica italiana dal 1945 a oggi, Florence: Giunti.

Waibl, H. (ed.) (1988) Alle radici della comunicazione visiva in Italia, Como: Centro di cultura grafica.

\title{
Biographical note
}

Davide Fornari holds a Ph.D. in Design Sciences from University luav of Venice and is a tenured teacherresearcher at SUPSI University of Applied Sciences and Arts of Southern Switzerland in Lugano, where he imparts classes of History of graphic design and typography.

\section{The diffusion of the Swiss Style in America: Jacqueline Casey and the MIT}

\author{
Louise Paradis / Independent Researcher / Los Angeles / USA
}

\begin{abstract}
The typographic style that developed in Switzerland post-World War II quickly gained recognition and became known as the International Typographic Style. In America, this style was embraced in corporate and institutional graphics during the late 1950s and throughout the 60s, and has remained a significant inspiration and aspect in the design field. The Massachusetts Insti-
\end{abstract}


tute of Technology (MIT) was one of the early institutions that demonstrated influences of the movement in the work produced by its graphic design office. Spearheading its involvement was American graphic designer Jacqueline Casey (1927-1992). In the mid-1950s, Casey recognized the exceptional expertise and accomplishment of Swiss graphic designers and established a connection with Therese Moll, who introduced Swiss typography, grids, and modular systems to the MIT office.

\section{Keywords}

Swiss Style, Diffusion, America, MIT, 1950s

\section{Introduction and context}

US-based graphic designer Jacqueline Casey (1927-92) is celebrated for her poster design work at MIT, in a career that spanned 30 years. She represents a generation of US designers who embraced the influential European and Swiss graphic movements of the 1950s and 60s, which we now recognize as International Typographic Style. Her work gracefully combines these influences with an innovative and distinctive approach. Casey is one of the few women practitioners from this period whose work received recognition in the official archives of graphic design history.

After the Second World War, a new leading design style was developed and perfected in Switzerland, more specifically in Zurich and Basel. The Swiss Style emphasizes objectivity, clarity, order, and is characterised by the use of systematic grids, sans serif typefaces, and asymmetric layouts. It soon outgrew its native boundaries and spread in America through different streams: publications, exhibitions, professional associations, teaching, and migration of designers. Moving to the United States in 1935, the Swiss designer Herbert Matter can be seen as a forerunner in this campaign. Around the 1950's and 1960's, we can observe many links and channels of dissemination for Swiss Style in America. Here are a few examples: Joseph Müller-Brockmann got notable attention by having his work published in American magazines and by organizing a touring exhibition. Armin Hoffmann became a visiting lecturer at Yale University, a bastion for modernism. Paul Rand cultivated friendships with Swiss designers through the Alliance Graphique Internationale group. Karl Gerstner published Die Neue Graphik and exhibited the work of his agency Gestner+Kutter in New York. Swiss expatriate designers working at Geigy in New York continued to work in the same manner.

Considering the American design context where many styles and attitudes evolved simultaneously, Swiss Style came to be embraced especially by corporate and institutional graphics. In fact, the development of American corporate design in the mid-60s is closely connected to the emergence of the International Typographic Style. With it, we saw the rise of design groups such as Chermayeff \& Geismar or Unimark specializing in the creation of identities and annual reports for multinational companies. In this male dominated arena, it is quite interesting to observe the influence of Swiss Style in the work produced by a woman, Jacqueline Casey, at the Massachusetts Institute of Technology (MIT).

\section{Foundation of MIT office of publication}

Shortly after taking a new position at MIT, John Mattill, journalism graduate, founded the MIT Office of Publications. He had realized that MIT publications - anything from promotions, student recruitment, fundraising, catalogues, and posters - would be printed without consistency in their look and voice. Sensitive to language from his journalism studies he also understood the value of design as he had taken a course at the University of lowa with the owner of private press Prairie Press, Carroll Coleman, who published elegant little books. Mattill thus came to appreciate the quality of typography and how graphic art works. Looking to hire a designer, he followed the recommendation of a teacher in the department of architecture who also taught at Massachusetts College of Art and Design, and hired Muriel Cooper in 1952, who was one of the first designers ever hired by the university. In 1955, Cooper recruited graphic designer and fellow MassArt alumna Jacqueline Casey. Ralph Coburn, an MIT architecture student, and Dietmar Winkler, a recent German immigrant, soon followed. They too would be influential in bringing the modern look to MIT.

In its early years, there was no obligation to use the MIT Office of Publications if one wanted to print something, but it was an available service. At first the office was only involved in the design of summer session materials, but soon the high quality of its work was acknowledged by the different faculties and offices. Without ever 
having a style book, the MIT Office of Publications created a modern and consistent identity devoted to excellence. Its look was restrained, functional, elegant, and intelligent - qualities shared by an important movement at the time, the International Typographic Style.

\section{Acknowledgement of Swiss Style}

The development of MIT's graphic identity was undoubtedly shaped by a practice of inviting visiting European designers to work on special programs for a few months every year. This exercise began in 1958, just as Cooper left the Office for a Fulbright Scholarship in Milan. As Mattill recalled: "I think it is probably Jackie more than anyone else who recognized that Swiss designers were the people with an exceptional expertise and accomplishment in graphic design and typography. Looking at Swiss publications, they were all beautifully designed, very restrained, very elegant, and very technically correct. Their typography reflected an intelligence and an understanding of formal principles. I can't remember the details of how it worked out but we got the name of a Swiss designer; Karl Gerstner" (John Mattil, in discussion with the author, April 2, 2015). For her part, Casey has acknowledged that "the people who had the most influence on me were Karl Gerstner and Kurt Wirth" (Casey \& Winkler, 1992, p. 1). Swiss designers were clearly held in high regard, and a contact was made with Karl Gerstner who recommended Therese Moll as a visiting designer. With a training in modular systems, Moll's utilization of proportions in design were soon the core of MIT's image. She also introduced the office to European typography and laid out the groundwork that is still being followed today (Casey \& Winkler, 1992, p. 17).

Therese Moll had studied at the Basel School of Design in Switzerland, then worked in the best studios of her day: Studio Boggeri in Milan, followed by Karl Gerstner and Geigy (Hollis, 2006, p. 163). She was a talented designer whose knowledge was gained through the best teachers and designers of her time. Unfortunately, her untimely death may have left her fade into oblivion. She undoubtedly deserves more recognition, as she was not only an outstanding designer who merits being considered equal to the Swiss masters of her time, but also had a direct hand in the dissemination of Swiss typography and design across the US.

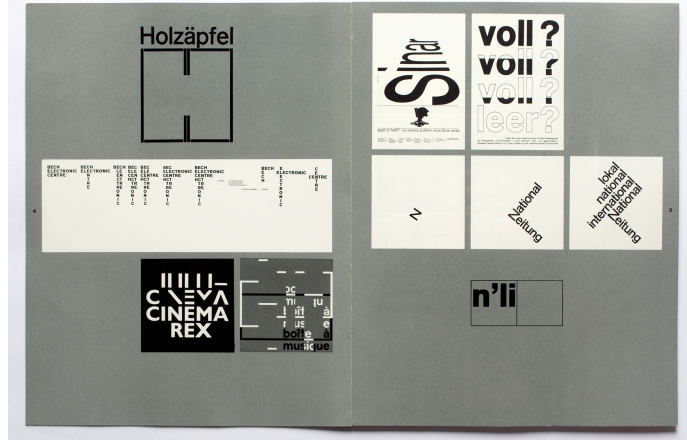

Fig. 1: Karl Gerstner, "typographisches memorandum", Typografische Monatsblätter, no. 2 (1972)
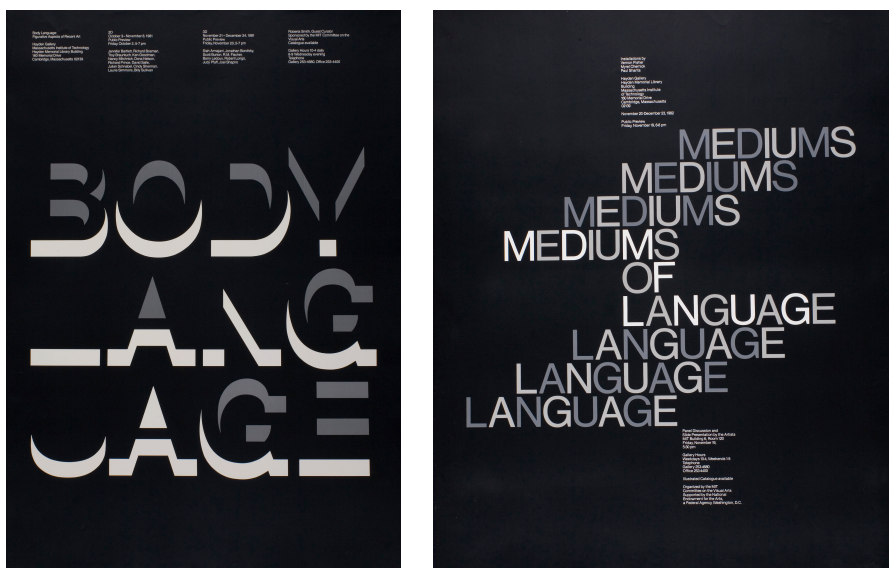

Fig. 2: Jacqueline Casey, "Body Language" (1981), "“Mediums of Languages" (1982)

\section{Casey's design approach}

As Casey had received a Certificate in Fashion and Illustration and a Bachelor of Fine Arts degree from the Massachusetts College of Arts, her education in graphic design really took place at MIT, working with Cooper and with visiting designers. And since she had no formal graphic design education, she developed her own way of working. Contrary to how most designers work, which involves making many variations and compositions for one assignment and then selecting the best one, she would only work on one artwork: "If you would have seen Jackie's desk, you would have wondered where she did her work. There was nothing on the desk, maybe some posters or exhibition catalogs; basically a white desk. She would hang her design up. She would get up, do something and come back and sit down and stare. She would work on the same artwork until she was satisfied with it. It was an optical process. It was very clever as this process made her always conscious of the environment in which the poster would be displayed" (Dietmar Winkler, in discussion with the author, March 31, 2015). Furthermore, Casey always had two things in mind when designing a poster: the audience and the artist or subject concerned. Her posters engage the intellect 
of the audience with a striking or puzzling image. She gracefully created relationships between words, images, and colors in a clever and minimalist manner. Black backgrounds were often favored as they provide a greater impact from the environment in which the posters would be displayed. Research was central to Casey's designs: "The most constant part of my approach to design has always been the search for information. It starts out with gathering material: an interview with the client, taking notes and establishing the client's objectives, a library visit, a search through the library stacks; determining the purpose of the communication, the audience, looking for any hint of special significance to make a more accurate and vital statement. Anything to represent the intelligence and quality which drives MIT" (Casey \& Winkler, 1992, p. I). What is more, she was resourceful - able to deliver high-quality artwork despite often working with limited budgets, and using office supplies such as sticky dots in compositions. She also used the IBM Selectric Composer, which used typewriter balls, with each ball providing a different typeface. This would reduce costs by avoiding outsourcing the work to a professional typesetter. When budgets allowed, Helvetica proved to be one of the typefaces she favored, asking, "Was there ever a more satisfying typeface?" (Casey \& Winkler, 1992, p. 27)

\section{A woman practitioner}

When discussing Jacqueline Casey, it is difficult to disregard certain feminist matter. Her work was featured in 1988 in Women in Design: A Contemporary View, and the introduction asserts: "Many women in the design field want to be acknowledged for the ideas and work they produce, as opposed to being singled out for the fact that they happen to be women" (McQuiston, 1988, p. 6). This was Casey's stance. However, the general context of graphic design in the US, in which she evolved, made her one of the few women in the field to earn an international reputation. She participated in competitions and gained good visibility in magazines, books and exhibitions. The MIT Office of Publications could have counted more women than men at some point - Muriel Cooper, Jacqueline Casey, Therese Moll, Elisabeth Ferry, Nancy Cahners - an unusual situation in those days. Some fellow workers recalled an office full of humor and liveliness where Casey's clear laugh would fill the room. Cooper may have acted as a leader in creating this particular environment: "She was single. She was very gutsy. She had so much energy. Where Muriel was, things moved. She made everybody respond to her energy. She was a woman who understood power at a time where most were less outspoken" (Dietmar Winkler, in discussion with the author, March 31, 2015). Casey may not have been as straightforward as Cooper; she was aware of the institution's limitations. Despite the progressive attitude at MIT, the lack of women in higher positions was evident, given that most were secretaries. She attended regular women's meetings at MIT in which discussions included the position of women at the institution. Feminism therefore seems to have been a concern for Casey, as well as a number of social and progressive causes. She collected anti-Vietnam War posters, which were later donated to Monserrat College of Art.

Some have suggested that the significant positions gained by Casey and her fellow female designer colleagues was due to the little money the jobs offered. Men went to higher paid graphic occupations, for example, annual reports were the new way to make big money. A new situation emerging at the time was noted by Henry Kay Henrion. According to him, the 1950s saw the poster as the most desirable medium, and thus most designers were poster designers. Henrion states: "It was the most glamorous, most seen and discussed medium in the wide spectrum of graphic design. Since then the poster has declined and many other facets of visual communication [...] have become equally and often more important" (Henrion, 1983, p. 8). Did a change in the profession and type of project create opportunities for women? Perhaps, but it would require larger and further discussion than this text allows.

\section{Legacy}

A long struggle with cancer affected the course of Casey's career, and in 1989 she became a visiting design scholar at the MIT Media Laboratory, until her death in 1992 ("Designer Jacqueline Casey Dies at 65," 1992). Few institutions achieved the excellence of MIT's identity and graphic materials. Casey should be remembered as one of its most devoted innovators and artisans. Furthermore, her work stands as a noteworthy example in the development of the International Typographic Style in America. 


\section{References}

Casey, J.S. and Winkler, D.R. (1992) Posters: Jacqueline S. Casey: Thirty Years of Design at MIT, Cambridge: MIT Museum.

Designer Jacqueline Casey Dies at 65 (1992, May 20), MIT News. Retrieved February 14, 2016, from http://newsoffice.mit.edu/1992/casey-0520.

Henrion, F.H.K. (1983) Top Graphic Design. Zurich: ABC Verlag.

Hollis, R. (2006) Swiss Graphic Design: The Origins and Growth of an International Style, 1920-1965. New Haven: Yale University Press.

McQuiston, L. (1988) Women in Design: A Contemporary View, New York: Rizzoli.

With thanks to Dietmar Winkler, Elizabeth Resnick, Elizabeth Ferry, Nancy Cahners, John Mattill, Ralph Coburn, Robert Wiesenberger for their time and advice.

\section{Biographical note}

Louise Paradis is an art director based in Los Angeles. She received a BA in graphic design from UQAM, Canada, and an MA in Art Direction from ECAL, Switzerland. Paradis is lead researcher and co-author of 30 Years of Swiss Typographic Discourse in the Typografische Monatsblätter published by Lars Müller. 